UDC 338.448

JEL: L83, Q56

\section{Olena Judina}

$\mathrm{PhD}$ in Economics, Associate

Professor,

Dnipro Humanities University, Dnipro, Ukraine

E-mail: e.i.yudina@mail.ru orcid.org/0000-0003-3699-5321

Received: December, 2019

Accepted: February, 2020

DOI:10.31520/2616-7107/2020.4.1-4

(C) Economics. Ecology. Socium, 2020

CC BY-NC 4.0 license

\section{ANALYSIS AND EVALUATION OF THE IMPACT OF PROGRESSIVE DEVELOPMENT ON ECONOMIC GROWTH AND SUSTAINABILITY OF HOTEL AND RESTAURANT BUSINESS}

Introduction. The problem of ensuring the economic sustainability of modern hotel and restaurant businesses is due to the need to ensure their sustainable development in a changing external environment, unstable market conditions, increased competition and rising prices for production resources. Advantages in solving these problems provide reduction of production costs, diversification of activities, novelty of products / services, technical and technological updating and improvement of material and technical base, improvement of management system, working conditions and financial condition of the enterprise, which is directly related to the economic efficiency of the business process. Since overall efficiency is the output of the production process and is defined as the ratio of output to cost of operations, and its increase provides an increase in economic effect, the most favourable economic conditions and competitive advantages in the market, the problem of establishing the relationship between efficiency gains and economic sustainability of enterprises is exacerbated.

Aim and tasks. The purpose of the study is to analyze and determine the degree of influence of the factors of progressive development on improving the efficiency of use of production resources and ensuring the stability of functioning of the enterprises of the hotel and restaurant business through modeling, calculation of indicators of progressive development.

Results. As a socio-economic system, an enterprise is characterized by complex multicomponent relationships between a large number of interdependent and interacting elements of different types, each of which can in turn be represented as a system (subsystem). The criteria of progressive economic development of the hotel and restaurant business enterprises are defined in the paper and the methods of their structural and component analysis are grounded. Models of pairwise regression between costs, types of capital investments and parameters of investment and innovation activity are constructed. The sequence of calculation of indicators of progressive economic development is offered.

Conclusions. Increasing the cost of new machinery and equipment, existing buildings and structures, new construction and acquisition of software are contributing to the growth of labor resource potential, reducing material consumption, and increasing the cost of production. On the basis of structural-component analysis regularities of differentiated mutual influence between the indices of production resources consumption and directions of investmentinnovative activity are determined, indicators of progressive development are used, by which it becomes possible to measure the level of efficiency of use of resource potentials, economic growth of the enterprises of the hotel and restaurant business.

Keywords: business, analysis, economic models, capital investments, innovation activity, progressive development. 
УДК 338.448

JEL: L83, Q56

\section{Олена Юдіна}

Кандидат економічних наук, доцент, завідувач кафедри готельноресторанного бізнесу, Дніпровський гуманітарний університет, Дніпро, Україна E-mail: e.i.yudina@mail.ru orcid.org/0000-0003-3699-5321

Отримано: Грудень, 2019

Прийнято: Лютий, 2020

DOI:10.31520/2616-7107/2020.4.1-4

(C) Економіка. Екологія. Соціум, 2020 CC BY-NC 4.0 ліцензія

\section{АНАЛІЗ ТА ОЦНКА ВПЛИВУ ПРОГРЕСИВНОГО РОЗВИТКУ НА ЕКОНОМІЧНЕ ЗРОСТАННЯ І СТІЙКІСТЬ ПІДПРИСМСТВА ГОТЕЛЬНО- РЕСТОРАННОГО БІЗНЕСУ}

Вступ. Проблема забезпечення економічної стійкості сучасних підприємств готельно-ресторанного бізнесу викликана необхідністю забезпечення їхнього сталого розвитку в умовах мінливого зовнішнього середовища, нестабільної ситуації на ринку, посилення конкуренції та зростання цін на ресурси виробництва. Переваги у вирішенні цих завдань забезпечують зниження витрат виробництва, диверсифікація діяльності, новизна продукції/послуг, техніко-технологічне оновлення та удосконалення матеріально-технічної бази, поліпшення системи управління, умов праці й фінансового стану підприємства, що безпосередньо пов'язано з економічною ефективністю процесу господарювання. Оскільки загальна ефективність являє собою підсумок розвитку процесу виробництва і визначається як співвідношення результатів до витрат діяльності, а іiі підвищення забезпечує збільшення економічного ефекту, найбільш сприятливі умови господарювання і конкурентні переваги на ринку, проблема встановлення взаємозв'язку між зростанням ефективності та економічної стійкості підприємств посилюється.

Мета і завдання. Метою дослідження $\epsilon$ аналіз та визначення ступеня впливу факторів прогресивного розвитку на підвищення ефективності використання ресурсів виробництва й забезпечення стійкості функціонування підприємств готельно-ресторанного бізнесу шляхом моделювання, обчислення індикаторів прогресивного розвитку.

Результати. Підприємство як соціально-економічна система характеризується складними багатокомпонентними зв'язками між значною кількістю взаємозалежних i взаємодіючих елементів різного типу, кожен з яких, в свою чергу, може бути представлено у вигляді системи (підсистеми). $\mathrm{y}$ роботі визначено критерії прогресивного економічного розвитку підприємств готельно-ресторанного бізнесу та обгрунтовано методи їхнього структурно-компонентного аналізу. Побудовано моделі парної регресії між витратами, видами капітальних вкладень та параметрами інвестиційноінноваційної діяльності. Запропоновано послідовність розрахунку індикаторів прогресивного економічного розвитку.

Висновки. Зростання рівня витрат на нові машини та обладнання, в існуючи будівлі та споруди, нове будівництво та придбання програмного забезпечення сприяють зростанню потенціалу ресурсу праці, зниженню матеріаломісткості, збільшенню фондомісткості виробництва. На підгрунті структурно-компонентного аналізу визначено закономірності диференційованого взаємовпливу між показниками витрат ресурсів виробництва та напрямами інвестиційно-інноваційної діяльності, обчислено індикатори прогресивного розвитку, за допомогою яких стає можливим виміряти рівень ефективності використання ресурсних потенціалів, економічного зростання підприємств готельно-ресторанного бізнесу.

Ключові слова: бізнес, аналіз, економіко-математичні моделі, капітальні вкладення, інноваційна діяльність, прогресивний розвиток. 
Introduction. The problem of ensuring the economic stability of businesses is caused by the necessity of their survival in the conditions of changing environment, instability of the market situation, increased competition and rising prices for production resources. Advantages in solving these problems are provided by such factors as reduction of production costs, diversification of activity, novelty of production, technical-technological updating and improvement of basic infrastructure, improvement of management system, labour conditions and financial condition of a business, which is directly related to economic efficiency and, therefore, the sustainability of a business entity. As the general effectiveness is the result of the process of production development and is defined as the ratio of results to the activity costs, and its increase provides an increase in economic effect, the most favourable economic conditions and competitive advantages in the market, today the relationship of increasing effectiveness and economic sustainability of hotel and restaurant businesses is increasing.

Analysis recent research and publications. Today, there is no common approach to assessing the economic stability of a business, but in terms of the systematic approach to ensuring economic growth and sustainability of a business, the obtained analytical parameters must be assessed taking into account the current conditions and patterns of its operation, the established trends of future development of business entities of hotel and restaurant sectors, as complex socio-economic systems, and the methods of structuralcomponent analysis are important and effective tools for studying economic systems.

The works of many scientists are devoted to solving the problems of analysis and assessment of economic growth and provision of economic sustainability.

The studies of Andrushkiv B. [2] are focused on indicators characterizing business resource costs and presentation of directions of their innovative development. In the works of Ansoff I. [1], Akoff R. and McDonnell E. [3] quantitative parameters of indicators are defined, which constitute the production potential but do not characterize the category of "economic development and growth".
Vasilenko V. [20] defines separate components, structural business divisions and processes, the effective management of which provides stability of operation and economic development through the use of management inventories by the organizational system. Merzlikina G. [16] considers sustainable economic development of a business as a state of its balance and think it advisable to manage the adaptability of a business entity to changes, first of all, of the external environment. In the work of Fedotova M. [10] the highest form of development that provides sustainability, is considered to be the maintenance of the balance of a business under the influence of external and internal factors, which proposes to create a system for managing the development of socialeconomic stability of a business. According to Raizberg B. [18] economic development of a business is based on the strengthening of its financial condition, which makes it possible to fulfil all obligations due to sufficient income. Medvedev V. [15] characterizes the sustainable economic development of a business as a process of creating an equilibria balanced state of economic resources, which provides stable profitability taking into account the most important external and internal factors.

Aim and tasks. The purpose of the study is to analyse and define the extent of influence of the factors of progressive development on improving the efficiency of production resource usage and providing the stability of operation of enterprises of the hotel and restaurant sector through and calculation of progressive development' indicators.

Results. A business as a socio-economic system is characterized by structurally and functionally complex multi-component systems with many interdependent and interacting elements (components) of different types, having numerous and heterogeneous relationships between them, and each element of this system can also be presented as a system (subsystems). Therefore, during the system analysis and assessment, the economic system of any complexity can be presented in the form of separate parts interconnected by certain relationships that interact with the external environment and are characterized by continuous development, and then it is advisable to solve the problematic situations arising in the 
system under study using the methods of decomposition, analysis and synthesis. Using the methods of modelling processes under study allows to assess the degree of settling a problem situation. The process of decomposition is based on component analysis, which involves studying the specifics, qualities and regularities of the development of system components based on the differentiation of its structural parts.

The process of economic growth is a manifestation of economic development, its component, which is characterized by increasing the volume of products (services), income, improving the performance indicators of a business. Economic growth implies improving quantitative performance parameters and is impossible in the long run without economic development, which creates the preconditions and conditions for economic growth on a new quality level and contributes to the sustainable development of a business entity $[5-6 ; 14 ; 20]$. And development is the process of qualitative transformation of the economic system from a certain state to an uncertain (negative or positive) one, depending on the level of efficiency of use of business resources, which affects the result and quality of business activity. So, the category "development" covers both regressive and progressive orientation associated with the process of transition from a less advanced to a more advanced state, from a lower to higher level, and vice versa. Today, the term "progress" (lat. progressus - onward movement) is most often defined as a direction of development characterized by a transition from a lower to a higher level, from a less advanced to a more advanced state.

That is, progressive development is a process of positive qualitative transformation of the economic system from a less advanced current state to a new one through the most efficient use of labour, material, technical, information, investment, financial and other types of resources for the purpose of improving the efficiency and quality of a business operation [8; 9; 11-12]. So, economic progress is a progressive development of an economic system, each of its elements, and the result of economic progress appear in real achievements in the process of economic development.

Innovations play a leading role in a progressive development of economic systems.
An innovative type of economic development is known to have a number of qualitative characteristics: it relies on modernization, involves the generation and use of new knowledge and technologies. Innovation is a key factor in the progressive and sustainable business development in the current conditions of strengthening global competition.

Innovation investment contributes to the economic growth of a business by updating and improving the material and technicaltechnological base, increasing production capacity. This gives the possibility to release new products (services), reduce their cost price, reduce the use of resources, and thus improve the efficiency of production and commercial activities and provides for business entities a transition to a higher level of intensive or progressive development.

Since the main source of progressive change is the development of contradictions (influencing factors) in the dynamics of processes that take place in economic systems, to the methods of defining these changes, their quantitative description, analysis, assessment and provision one can attribute:

- creation of economic-mathematical models of dependence and assessment of quantitative interaction and mutual influence of elements of the economic systems under study (businesses);

- establishment of laws and scientifically substantiated trends of dynamic development of an economic system and its components;

- definition of indicative criteria of the assessment of the level of influence of progressive changes on the resource potential of a business as a system on the basis of investment-innovation processes;

- creation of investment flows (amount of capital investment) and definition of directions of their most efficient use;

- creation of economic mechanisms of sustainable development on the basis of economic laws and structural interconnections of the components of the system under study;

- creation of qualitatively new forms of production organization, their adaptation to new environmental conditions;

- development of models of business sustainable economic growth management on the basis of progressive development $[13 ; 19]$. 
And the criteria of the assessment of the progressive economic development of the hotel and restaurant sector businesses are: updating and improving the basic infrastructure of a business; technical and technological updating; introduction of new information technologies and software; raising the level of labour resource development (increase of professionalism, qualification of the personnel of a business, intellectualization and automation of working processes).

Structural-component analysis depending on the level of detail of the description of complex economic systems, which are enterprises of the hotel and restaurant business, and differentiation of their elements, implies such levels of modelling:

- structural modelling of complex economic systems using their algorithmic models and statistical modelling;

- logical modelling of functional elements of complex economic systems that are created in the form of equations of direct relationships (logical equations);

- quantitative modelling of elements of complex economic systems that are presented as the systems of non-linear algebraic or integral and differential equations and are studied using the methods of functional analysis and mathematical statistics.
So, to determine the level of dependence of factors of consumption of production resources on the amount of a certain type of capital investments in the enterprises of the hotel and restaurant business, it is necessary to perform a number of analytical tasks, including: construction of economicmathematical models of interaction of elements of the systems under study for assessment of their quantitative mutual influence; correlation-regression analysis of the dependence of consumption of production resources on the level and structure of capital investments in existing buildings and facilities, $\left(\bar{I}_{P M}\right)$, in new construction and reconstruction of buildings $\left(\bar{I}_{H C}\right)$, in new machines and equipment $\left(\bar{I}_{M O}\right)$, in software acquisition $\left(\bar{I}_{I T}\right)$; establishment of laws and scientifically substantiated trends of dynamic development of the economic system and its components; calculation of indicative criteria of assessment of the impact level of progressive changes on the development of resource capacities of a business as a socioeconomic system based on investment and innovation processes (See Fig. 1) [4; ].

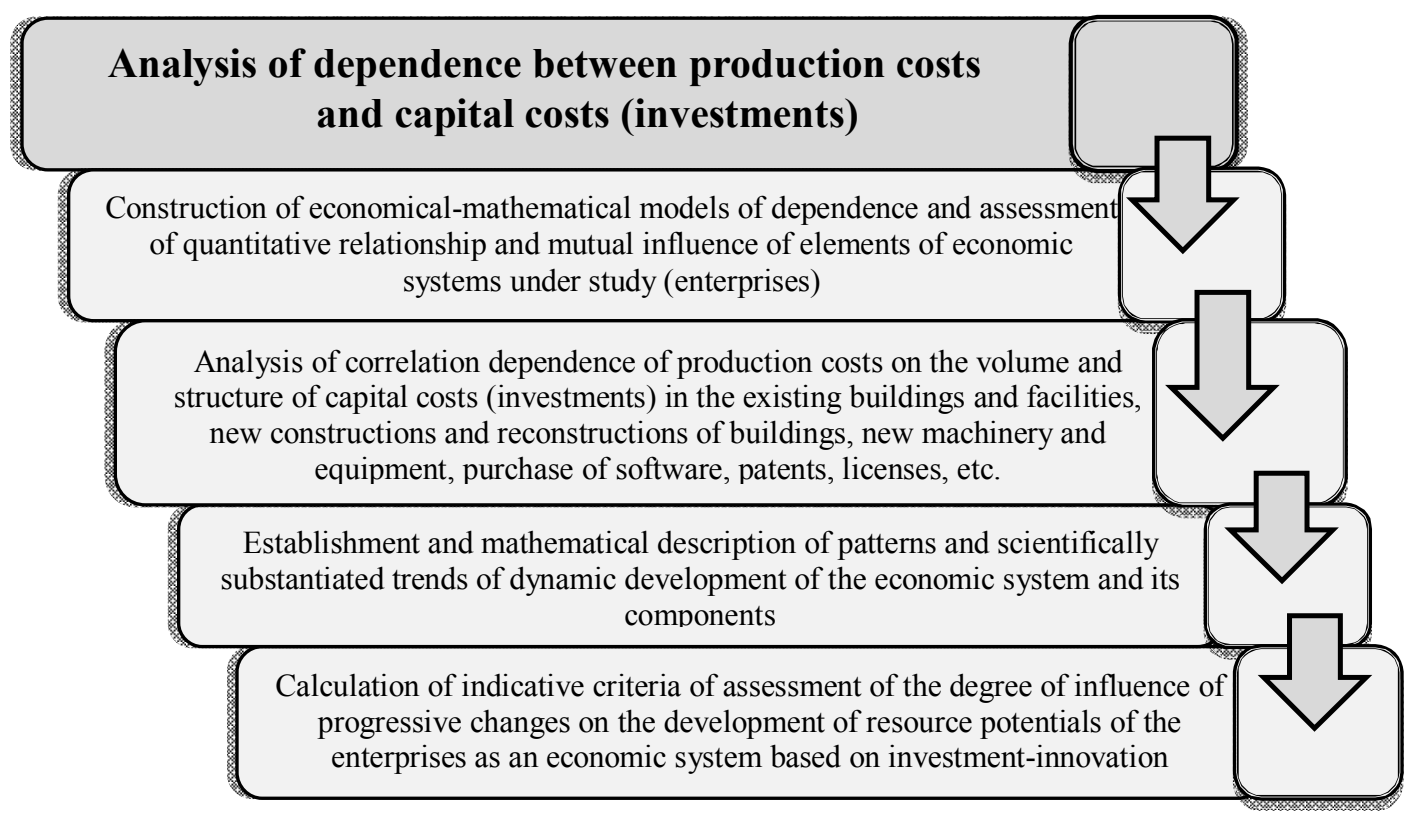

Fig.1. The task of analysis of the dependence of production costs on the amount of capital investments (costs) in certain areas in the enterprise of the hotel and restaurant business

Source: author's development 
Analysis and assessment of the impact of capital (investment-innovation) costs by areas on the level of material costs $\left(\mathrm{K}_{\mathrm{MB}}\right)$, the level of labour costs $\left(\mathrm{K}_{\mathrm{B \Pi P}}\right)$, the level of fixed asset costs $\left(\mathrm{K}_{\mathrm{BO \Phi}}\right)$ per monetary unit of total operating costs are carried out using these coefficients, which represent the ratio of the amount of a certain type of capital investment or investmentinnovation costs to the total operating costs of a enterprise of the hotel and restaurant business. Using the correlation-regression analysis, the level and form of relationships between the economic indicators under study are defined, differentiated measurement of the strength of relationships of factorial features (component), which include the coefficients of capital costs and non-incidental effective features or costs of resource for manufacturing of products (services) of an enterprise of the hotel and restaurant business is performed $[7 ; 17 ; 22-23]$. The constructed economic-mathematical models of the patterns of interaction of costs by elements of operating activities and factors (coefficients) of progressive development are given in Table 1.

\section{Table 1. Models of pairwise regression of costs by elements of operating activity based on the level of costs by areas of investment-innovative activity of enterprises of hotel and restaurant business of Dnipropetrovsk region}

\begin{tabular}{|c|c|c|}
\hline No. & Model of correlation dependence of: & Regression model \\
\hline 1 & $\begin{array}{c}\text { material costs on the costs of new machinery } \\
\text { and equipment (1.1) }\end{array}$ & $\hat{K}_{M B I_{M O}}=0,0446 * \bar{I}_{M 0}^{3}-0,5887 * \bar{I}_{M O}^{2}+2,4492 * \bar{I}_{M O}-2,7851$ \\
\hline 2 & $\begin{array}{c}\text { material costs of existing buildings and } \\
\text { facilities (1.2) }\end{array}$ & $\hat{K}_{M B_{P M}}=6,7797 * \bar{I}_{P M}^{3}-5,6789 * \bar{I}_{P M}^{2}+1,0136 * \bar{I}_{P M}+0,3718$ \\
\hline 3 & $\begin{array}{l}\text { material costs on the costs of new } \\
\text { construction }(1.3)\end{array}$ & $\hat{K}_{M B I_{H C}}=0,0003 * \bar{I}_{H C}^{3}-0,0105 * \bar{I}_{H C}^{2}+0,0873 * \bar{I}_{H C}+0,2054$ \\
\hline 4 & material costs on the costs of software (1.4) & $\hat{K}_{M B I_{I T}}=1477 * \bar{I}_{I T}^{3}-408,31 * \bar{I}_{I T}^{2}+34,942 * \bar{I}_{I T}-0,5876$ \\
\hline 5 & $\begin{array}{c}\text { labour resource costs on the costs of existing } \\
\text { buildings and facilities (1.5) }\end{array}$ & $\hat{K}_{B \Pi P I_{P M}}=-13,235 * \bar{I}_{P M}^{3}+12,28 * \bar{I}_{P M}^{2}-3,221 * \bar{I}_{P M}+0,455$ \\
\hline 6 & $\begin{array}{c}\text { labour resource costs on the costs of new } \\
\text { construction (1.6) }\end{array}$ & $\hat{K}_{B \Pi P I_{H C}}=-0,00006^{*} \bar{I}_{H C}^{3}+0,0018^{*} \bar{I}_{H C}^{2}-0,0096 * \bar{I}_{H C}+0,2294$ \\
\hline 7 & $\begin{array}{l}\text { labour resource costs on the costs of } \\
\text { software acquisition (1.7) }\end{array}$ & $\hat{K}_{B I I P I_{I T}}=-647,09 * \bar{I}_{I T}^{3}+157,13 * \bar{I}_{I T}^{2}-10,789 * \bar{I}_{I T}+0,4553$ \\
\hline 8 & $\begin{array}{l}\text { BPA (basic production assets) costs on the } \\
\text { costs of new machinery and equipment (1.8) }\end{array}$ & $\hat{K}_{B O \Phi_{I O}}=-0,0008 * \bar{I}_{M 0}^{3}+0,0113 * \bar{I}_{M O}^{2}-0,0456 * \bar{I}_{M O}+0,1379$ \\
\hline 9 & $\begin{array}{c}\text { BPA costs on the costs of existing buildings } \\
\text { and facilities (1.9) }\end{array}$ & $\hat{K}_{B O \Phi I_{P M}}=0,6594 * \bar{I}_{P M}^{3}-0,5381 * \bar{I}_{P M}^{2}+0,1558 * \bar{I}_{P M}+0,0727$ \\
\hline 10 & $\begin{array}{l}\text { BPA costs on the costs of new construction } \\
(1.10)\end{array}$ & $\hat{K}_{B O \Phi I_{H C}}=-0,00002 * \bar{I}_{H C}^{3}+0,0006 * \bar{I}_{H C}^{2}-0,0009 * \bar{I}_{H C}-0,0772$ \\
\hline 11 & $\begin{array}{l}\text { BPA costs on the costs of software } \\
\text { acquisition (1.11) }\end{array}$ & $\hat{K}_{B O \Phi I T T}=-278,65 * \bar{I}_{I T}^{3}+82,718 * \bar{I}_{I T}^{2}-7,7896 * \bar{I}_{I T}+0,3243$ \\
\hline
\end{tabular}

Source: author's development

Creating regression models of relationship of the resulting indicators of production costs and capital investment factors by areas allows to establish the extent of influence of costs by types of investment-innovation activity on the development of the economic indicators under study, taking into account the dynamics of progressive changes (development). For this purpose, on the basis of the presented economic-mathematical models $(1.1 ; 1.2 ; 1.3$; $1.4 ; 1.5 ; 1.6 ; 1.7 ; 1.8 ; 1.9 ; 1.10 ; 1.11)$ and general formulae (1), indicators of progressive economic development of the parameters of resource costs in the process of production are calculated depending on the level of capital investment in new machinery and equipment, existing buildings and facilities, new construction, software acquisition:

$$
J_{K_{i I_{j}}} \hat{=} \frac{f^{\prime}\left(\hat{K}_{i I_{j}}\right) * \bar{I}_{j}}{f\left(\hat{K}_{i I j}\right)},
$$


where $J_{K_{i I_{j}}}-$ indicator of progressive economic development of the potential of the $i$-th production resource depending on the level of the $j$-th type of capital investments; $f^{\prime}\left(K_{i I_{j}}\right)$ - derivative function of costs of the $i$-th resource and the level of the $j$-th type of capital investments; $\bar{I}_{j}-$ average value of the $j$-th factor of capital costs.

Calculated using the presented formula, the values of progressive development indicators demonstrate that increasing the level of costs of new machinery and equipment, existing buildings and facilities, the level of costs of new construction and the level of costs of software acquisition by $1 \%$ leads to increasing the capital intensiveness of production by $0.32 \%, 0.08 \%, 0.37 \%, 0.24 \%$ and influences decreasing the indicator of material content by $1.23 \%, 0.23 \%, 1.07 \%$ and $0.63 \%$, respectively. It has also been proven that increasing the amount of investment in existing buildings and facilities, the level of costs of new construction and the level of costs of software acquisition by $1 \%$ contribute to increasing the labour resource potential by $0.68 \%, 0.34 \%$ and $0.58 \%$, respectively.
The model of regression of labour costs and the costs of new machinery and equipment has a low level of correlation dependence and is not considered in a further study.

Conclusions. The models of correlation dependence of production resources and capital costs, which are factors that influence the efficiency of operation and economic growth of an enterprise, that were constructed during the analysis allow to establish the degree of reduction of resource intensiveness and economic growth and, consequently, the level of sustainable economic development of an economic entity through capital investments, i.e. the creation of the required volume of investments and their use in the planned areas, since sustainable economic development is ensured by stable economic growth, which is based on improving performance at the cost of the development of the resource potentials of an enterprise and targeted use of investments, which in turn creates the conditions for the creation of efficient model of management of sustainable economic development of an enterprise of the hotel and restaurant business.

\section{REFERENCES}

1. Ackoff, R. (1981). Creating the Corporate Future: Plan or Be Planned For. New York: John Wiley \& Sons.

2. Andrushkiv B.M. Vovk, Yu. Ya, Vovk, E. P., Palyanitsya, V. Pogaydak, O. \& Stoyko, I. (2012). Resource economics: theoretical and applied aspects. Ternopil: Terno-graf. [in Ukrainian].

3. Ansoff, H., \& McDonnell, E. (1990). Implementing Strategic Management. London: Prentice Hall International.

4. Arsenyev, Y., Potemkin, L., Filyppova, S., Bratus, H., \& Nikola, S. (2019). Internal audit of activity results at enterprises of hotel and restaurant business. Academy of Accounting and Financial Studies Journal, 23(2).

5. Bagur-Femenías, L., Perramon, J., \& Oliveras-Villanueva, M. (2019). Effects of service quality policies in the tourism sector performance: An empirical analysis of Spanish hotels and restaurants, Sustainability, 11(3), 872.

6. Bharwani, S., Mathews, D., \& Ghura, A.S. (2019). Business model innovation in the Indian hospitality industry: A study of the willingness to outsource specialty restaurants in luxury hotels, Worldwide Hospitality and Tourism Themes, 11(4).

7. Borodich S.A. (2010). Econometrics. Minsk: Novoe znanie. (in Belarus) 
8. Bowen, J., \& Morosan, C. (2018). Beware hospitality industry: the robots are coming, Worldwide Hospitality and Tourism Themes, 10(6).

9. Della Volpi, Y., \& Paulino, S.R. (2018). The sustainability of services: Considerations on the materiality of accommodation services from the concept of life cycle thinking, Journal of Cleaner Production, 192.

10. Fedotova, M.A. (2011). How to assess the financial stability of the enterprise. SPb.: Izdatelstvo Lan. (in Russian)

11. Koval, V., Mykhno, Y., Antonova, L., Plekhanov, D., \& Bondar, V. (2019). Analysis of environmental factors' effect on the development of tourism. Journal of Geology, Geography and Geoecology, 28(3).

12. Kuhzady, S., \& Ghasemi, V. (2019). Factors influencing customers' satisfaction and dissatisfaction with hotels: A text-mining approach, Tourism Analysis, 24(1).

13. Lestari, R.A., \& Faturohman, T. (2019). The implementation of qualitative comparative analysis (QCA) to define the working capital management strategy of hotels in Indonesia, International Journal of Trade and Global Markets, 12(3-4).

14. Lueckl, J., Weyermair, K., Matt, M., Manner, K., \& Fuchs, K. (2019). Results of official food control in Austria 2010-2016. Food Control, 99.

15. Medvedev, V.A. (2010). Sustainable development of society: models, strategy. Moscow: Akademiia. (in Russian)

16. Merzlikina, G.S. (2009). Economic viability of production systems. Moscow: Vy`sshaia shkola. (in Russian)

17. Radchenko, S.G. (2010). Stands for estimating statistical models. Kiev: PP "Sansparel”. (in Ukrainian)

18. Raizberg, B. (2009). Market economy. Moscow: Delovaia zhizn`. (in Russian)

19. Setiadi, R. (2019). Assessment of utilization of social media marketing for providing reliable information-based decision making for business service excellence in hotel sector. Journal of Management Information and Decision Science, 22 (4).

20. Vasilenko, A.V. (2005). Sustainable Enterprise Management. Kyiv: Tsentr uchebnoyj literatury [in Ukrainian].

21. Verevka, T.V. (2019). Development of industry 4.0 in the hotel and restaurant business. IBIMA Business Review, 324071.

22. Kostetska, K., Khumarova, N., Umanska, Y., Shmygol, N., \& Koval, V. (2020). Institutional qualities of inclusive environmental management in sustainable economic development. Management Systems in Production Engineering, 28 (2), 15-22. https://doi.org/10.2478/mspe-2020-0003

23. Kvach, Y., Koval, V., \& Hrymaliuk, A. (2018). Tourism and hospitality industry in the context of global economic development. Economics. Ecology. Socium, 2(4), 11-21. doi.org/10.31520/2616-7107/2018.2.4-2 